\title{
Komunitas SLiMS Semarang sebagai ruang inovasi pustakawan
}

\author{
Mochammad Riski Destrianto' ${ }^{1}$, Heriyanto² \\ ${ }_{1}^{1}$ UPT Perpustakaan Pusat Institut Pertanian Stiper \\ Jl. Nangka II Maguwoharjo, Depok, Sleman, Daerah Istimewa Yogyakarta, 55282 \\ 2Program Studi Ilmu Perpustakaan, Universitas Diponegoro \\ Jl. Prof. Soedarto, Tembalang, Semarang, Jawa Tengah, 50272 \\ E-mail: 1riskidestrianto@instiperjogja.ac.id, 2heriyanto@live.undip.ac.id
}

Received: September 2019; Accepted: September 2020; Published: December 2020

\begin{abstract}
Senayan Library Management System (SLiMS) software formed by SLiMS developers in 2008. Members of the SLiMS Community are librarians who play an important role in making innovations from interactions in an exchange of knowledge and produce various works. This study aimed to identify the Semarang SLiMS Community as a space for librarians' innovation in developing their competence. The method used is qualitative with a case study approach. Collecting data techniques was carried out using semi-structured interviews with four informants. The collected data was then analyzed using thematic analysis. Analysis results showed that the SLiMS Community was a space for librarians to improve their competence, especially in the field of SLiMS development. The patterns identified included motivation, knowledge sharing, collaboration, and innovation. Motivational factors included the desire to share knowledge, increase competence, and raise professional degrees to job demands. The second stage is knowledge sharing, conducted using 'Sinau Bareng', 'Library Clinic', workshops, and others. The third stage of collaboration is the interaction of community members with other communities to produce innovations. The last stage is innovation, describing outputs or achievements such as products, ideas, and new activities. Innovation is the beginning of the formation of new knowledge. This study concludes that the Semarang SLiMS Community can generate knowledge cycles that lead to innovation.
\end{abstract}

Keywords: Community of practice; Knowledge sharing; Senayan Library Management System; Librarian; Innovation

\begin{abstract}
Abstrak
Perangkat lunak Senayan Library Management System (SLiMS) dibentuk para pengembang awal SLiMS tahun 2008. Anggota komunitas SLiMS ialah pustakawan yang berperan penting membuat inovasi dari interaksi dalam pertukaran pengetahuan dan menghasilkan karya yang beragam. Penelitian ini bertujuan mengidentifikasi Komunitas SLiMS Semarang sebagai ruang inovasi bagi pustakawan dalam pengembangan kompetensi. Metode yang digunakan adalah kualitatif melalui pendekatan studi kasus. Teknik pengumpulan data melalui wawancara semi terstruktur dengan empat orang informan. Data yang terkumpul kemudian dianalisis dengan menggunakan thematic analysis. Hasil analisis menunjukkan bahwa Komunitas SLiMS sebagai ruang bagi pustakawan dalam meningkatkan kompetensi sebagai komunitas praktik (community of practice) khususnya di bidang pengembangan SLiMS. Pola yang diidentifikasi meliputi motivasi, berbagi pengetahuan, kolaborasi, dan inovasi. Faktor motivasi berupa keinginan berbagi pengetahuan, meningkatkan kompetensi, mengangkat derajat profesi, hingga tuntutan pekerjaan. Tahap kedua yakni berbagi pengetahuan yang dilakukan dengan cara "Sinau Bareng", "Klinik Perpustakaan", pelatihan dan lain-lain. Tahap ketiga kolaborasi berupa interaksi anggota komunitas dengan komunitas lain dalam rangka menghasilkan inovasi baru. Tahapan terakhir adalah inovasi, yang menggambarkan luaran atau capaian, misalnya produk, ide, hingga kegiatan baru. Inovasi sebagai awal terbentuknya pengetahuan baru. Kesimpulan penelitian adalah Komunitas SLiMS Semarang sebagai ruang inovasi mampu memunculkan siklus pengetahuan yang mengarah ke sebuah inovasi yang diawali dari motivasi, berbagi pengetahuan, kolaborasi, hingga produk dari inovasi.
\end{abstract}

Kata Kunci: Komunitas praktik; Berbagi pengetahuan; Senayan Library Management System; Pustakawan; Inovasi 


\section{PENDAHULUAN}

Eksistensi SLiMS terus meningkat tidak lepas dari adanya komunitas SLiMS yang dibentuk para pengembang awal bernama SLiMS Developer Community (SDC) pada 2008. SDC bertugas sebagai tim utama dalam pengembangan software. Di mana, para developer dan komunitas pengembang SLiMS terus melakukan perbaikan software hingga semakin kompleks namun semakin mudah digunakan (Widodo, 2016). Pada perkembangannya, komunitas SLiMS Indonesia, beranggotakan pustakawan, guru, hingga programmer yang tertarik dengan teknologi informasi bidang perpustakaan. Komunitas SLiMS mampu membuat para anggota memiliki kemampuan inovatif sehingga mampu membuat sebuah karya.

Salah satunya ialah Komunitas SLiMS Semarang sebagai salah satu komunitas yang masih aktif. Komunitas ini berdiri 2014 sampai saat ini yang telah membuat beragam kegiatan berbasis pertukaran pengetahuan seputar perpustakaan, khususnya seputar pengembangan SLiMS yang telah menghasilkan banyak inovasi dan karya. Adapun inovasi di komunitas SLiMS Semarang berangkat dari inovasi individu atau bersama-sama/kelompok. Beberapa contoh inovasi yang melibatkan komunitas ini adalah pengembangan SLiMS Setiadi, pengembangan aplikasi Electronic Dewey Decimal Classification $(E-D D C)$ versi 23 , tim pengembang utama SLiMS, serta produk berupa plug-in, tools, dan tutorial terkait SLiMS. Komunitas SLiMS mampu berperan penting sebagai ruang inovasi pustakawan, di mana kegiatan knowledge sharing dan praktik menjadi aktivitas utama mayoritas anggota yang memiliki profesi sebagai pustakawan.

Untuk itu, penelitian ini dilakukan untuk mengeksplorasi proses ruang inovasi pustakawan di Komunitas SLiMS wilayah Semarang. Peneliti akan mengetahui inovasi apa yang dilakukan komunitas ini dan bagaimana sebuah inovasi melalui komunitas praktik atau Community of Practice (CoP) dapat terbentuk hingga berhasil menciptakan individu yang kolaboratif juga inovatif. Community of practice dapat didefinisikan sebagai sekelompok orang yang berbagi perhatian atau keinginan terhadap suatu hal dan belajar melakukannya dengan lebih baik karena mereka melakukan interaksi secara berkala (Wenger-Trayner, \& Wenger-Trayner, 2015). Komunitas di sini mengacu pada struktur sosial yang melakukan interaksi dan membangun hubungan melalui sebuah pembelajaran yang terfasilitasi. Pada praktiknya, kegiatan ini ialah kegiatan yang terencana dalam berbagi pengalaman, ide, alat, cerita, hingga cara menangani masalah. Kata lain, "practice" merujuk pada kegiatan berbagi pengetahuan (Abou-Setta, 2015).

Community of practice sebagai ruang inovasi sebuah organisasi. Di mana pengetahuan dan pembelajaran merupakan pendorong utama dalam meningkatkan kinerja organisasi. Selain itu, anggota community of practice pun mendapatkan potensi pengetahuan yang muncul dari dirinya sendiri atau dari luar lingkaran tersebut. Maka, muncul pertanyaan besar mengenai bagaimana memaksimalkan nilai dan dampak dari pengetahuan yang terkandung dalam setiap individu tersebut. Berdasarkan hal ini, community of practice memiliki beberapa tujuan. Pertama, community of practice sebagai panduan dalam melaksanakan kegiatan knowledge sharing agar berjalan dengan baik sesuai rencana. Kedua, community of practice sebagai sebuah 
strategi dalam mempromosikan pembelajaran dan pengajaran sesuai tugas dan fungsi dalam penyelesaian masalah, menggali praktik, perilaku, dan kebiasaan yang terbaik dalam menumbuhkan inovasi.

Adapun penelitian Britt and Paulus (2016) membahas mengenai studi kasus \#Edchat pada Twitter. Informan penelitian ini berjumlah 8 orang yang berlatar belakang guru. Kelompok \#Edchat membantu anggotanya, para guru untuk saling tukar menukar informasi. Komunikasi yang berjalan sesama anggota \#Edchat telah membantu hubungan yang baik dan timbul timbal balik yang berkepanjangan. Selain itu, pesan (chat) memudahkan antar anggota untuk secara terbuka saling mengenalkan diri, membantu penyelesaian masalah seputar pengajaran, dan arus informasi bertema pendidikan yang cepat diterima anggota.

Penelitian Britt and Paulus (2016) ternyata memiliki kesamaan dengan penelitian yang peneliti teliti, mengenai Komunitas SLiMS Semarang sebagai ruang inovasi pustakawan. Komunitas berperan sebagai community of practice yang membantu anggota menerima pengetahuan sesuai kajian keilmuan komunitas tersebut. Komunitas SLiMS Semarang merupakan lembaga non profit yang bergerak dalam bidang aplikasi otomasi sistem katalog elektronik perpustakaan. Komunitas SLiMS membantu anggotanya dalam menyelesaikan permasalahan pengolahan koleksi perpustakaan menggunakan perangkat lunak.

Anggota Komunitas SLiMS Semarang sebagai bagian community of practice diharapkan dapat menggunakan pengetahuan komunitas untuk memecahkan masalah yang mereka hadapi serta mendapatkan berbagi solusi dari komunitas. Senada dengan pernyataan Mohajan (2017) yang menyatakan bahwa pada skala lebih besar, community of practice dimanfaatkan untuk meningkatkan inovasi dan mempromosikannya melalui berbagi praktik terbaik. Komunitas SLiMS Semarang mampu merangsang kreativitas anggota untuk mengembangkan perpustakaan. Selain itu, komunitas melalui community of practice pun dapat membantu menemukan inovasi, saling berbagi ide, alat, informasi, gaya, bahasa, cerita, dokumen, seperangkat kerangka kerja, serta perangkat lain (Ranmuthugala, Plumb, Cunningham, Georgiou, Westbrook, \& Braithwaite, 2011). Dengan demikian, komunitas melalui community of practice sebagai wadah anggota untuk mengekspresikan diri dan berkembang dalam kajian ilmu yang sedang dipelajarinya. Maka, penelitian ini bertujuan untuk mengidentifikasi komunitas SLiMS Semarang sebagai ruang inovasi bagi pustakawan dalam pengembangan kompetensi pustakawan.

\section{METODE PENELITIAN}

Penelitian ini menggunakan metode kualitatif melalui pendekatan studi kasus sebagai metode yang sesuai untuk penelitian ini. Penelitian kualitatif dapat dimanfaatkan untuk penelitian yang bertujuan untuk menelaah latar belakang peristiwa, misalnya tentang motivasi, peranan, nilai, sikap, dan persepsi (Moleong, 2017). Peneliti dalam teknik pengambilan data melakukan wawancara semi terstruktur. Peneliti mewawancarai ketua dan anggota Komunitas SLiMS Semarang yang aktif mengikuti kegiatan komunitas termasuk membuat beberapa inovasi. 
Adapun dalam menentukan informan penelitian, peneliti menggunakan teknik purposive sampling, yaitu teknik pengambilan sampel sumber data dengan pertimbangan tertentu (Sugiyono, 2016). Peneliti memilih informan sesuai kriteria sebagai berikut, yakni informan yang memiliki profesi sebagai pustakawan, anggota inti komunitas SLiMS Semarang, dan pernah membuat inovasi yang berkaitan dengan aplikasi SLiMS berupa modifikasi, plug-in, tools, tutorial, produk, jasa, dan kegiatan yang bertemakan SLiMS. Informan yang memenuhi kriteria tersebut berjumlah 4 orang dan bersedia untuk diwawancarai sebagai informan.

Peneliti setelah memperoleh data melalui wawancara kemudian melakukan analisis menggunakan thematic analysis, yakni teknik menganalisis data untuk mengidentifikasi pola dari fenomena yang sedang dikaji (Heriyanto, 2018). Proses ini terdiri dari beberapa tahapan. Pertama pemahaman data. Pemahaman data dilakukan melalui mendengarkan kembali setiap rekaman wawancara yang telah dilakukan. Peneliti selama mendengarkan rekaman wawancara, mencatat beberapa hal penting yang diperoleh dari setiap informan. Selanjutnya rekaman tersebut ditulis ke dalam bentuk teks untuk memudahkan dalam pemahaman isi wawancara dan memudahkan proses analisis ke tahap berikutnya.

Kedua, tahap penentuan kode. Peneliti dalam menentukan kode (coding), memberikan kode terhadap potongan teks wawancara yang dianggap relevan dengan topik penelitian dan dapat menjawab rumusan masalah. Kode merupakan pilihan kata atau frasa yang ditentukan untuk memunculkan makna sesuai dengan teks yang sedang dianalisis.
Ketiga, tahap mengelompokkan kode. Peneliti setelah menentukan kode lalu kode tersebut dipindahkan ke dalam tabel dan dibuat beberapa kelompok kode sesuai makna masing-masing. Kode yang memiliki makna yang serupa dikelompokkan dalam satu tabel yang sama. Kemudian di akhir kegiatan diperoleh beberapa kelompok kode dengan makna yang serupa.

Keempat, tahap memberikan nama yang sesuai untuk setiap kelompok kode tersebut atau disebut juga sebagai penentuan tema. Nama kelompok diilustrasikan sesuai kelompok kode atau tema. Peneliti memeriksa kembali nama tema dengan isi kode untuk menentukan tema akhir. Tema akhir inilah yang akan dibahas sebagai hasil artikel.

Tema merupakan jawaban dari pertanyaan penelitian, maka peneliti dalam memilih tema melakukan secara hati-hati dan rinci. Setiap anggota penelitian bekerja dan berdiskusi secara intensif dalam menentukan nama (tema) yang tepat untuk setiap kelompok. Proses ini dapat dilakukan beberapa kali untuk melihat kembali transkrip wawancara. Hal ini berguna untuk memastikan bahwa kode yang dipilih sudah mencerminkan informasi yang diberikan informan, sekaligus memastikan setiap kode berada dalam kelompok yang tepat. Nama-nama tema disajikan di tabel 1.

Selanjutnya hasil temuan memasuki pemeriksaan keabsahan hasil analisis terhadap data. Data hasil analisis kemudian dikendalikan melalui implementasi dalam menjaga kualitas penelitian, meliputi credibility, transferability, dependability, dan confirmability (Sugiyono, 2016). 
Tabel 1

Penentuan tema final

\begin{tabular}{ll}
\hline Kelompok motivasi & $\begin{array}{l}\text { Tema final } \\
\text { motivasi }\end{array}$ \\
\hline $\begin{array}{l}\text { Knowledge sharing dan } \\
\text { praktik }\end{array}$ & Knowledge sharing \\
Interaksi & \\
Virtual knowledge sharing & \\
Meningkatkan proses & \\
belajar & \\
Kolaborasi & Kolaborasi \\
Inovasi & Inovasi \\
\hline
\end{tabular}

Sumber: Hasil pengolahan data, 2019

Credibility merupakan uji kepercayaan terhadap hasil dari suatu penelitian yang telah disajikan oleh peneliti serta untuk membuktikan apakah yang diamati oleh peneliti benar-benar telah sesuai dengan fakta di lapangan. Pengujian terhadap kredibilitas dalam penelitian ini dilakukan melalui cara sebagai berikut, a) meningkatkan kecermatan dalam penelitian, b) member check, dan c) bukti tambahan dengan bahan referensi. Transferability, merupakan upaya peneliti dalam rangka menunjukkan temuan penelitian sesuai konteks penelitian. Dependability peneliti harus mampu menunjukkan jejak aktivitas lapangan mulai dari proses penentuan masalah, terjun ke lapangan, pengolahan dan analisis data, melakukan pengendalian kualitas data yang telah diperoleh, dan pembuatan laporan penelitian. Validitas hasil penelitian dilakukan melalui diskusi antar tim peneliti seputar proses analisis data, taraf kebenaran serta penafsirannya. Anggota kedua penelitian ini mengamati, mengawasi sekaligus memastikan bahwa proses analisis data dilakukan oleh anggota pertama secara tepat. Adapun langkah terakhir yaitu confirmability, konfirmasi untuk mengetahui data apakah data yang diperoleh objektif atau tidak melalui pengujian hasil penelitian dan dikaitkan dengan proses penelitian.

\section{HASIL DAN PEMBAHASAN}

Berdasarkan hasil analisis data ditentukan 4 tema mengenai peran Komunitas SLiMS Semarang sebagai ruang inovasi pustakawan antara lain motivasi sebagai modal awal berinovasi, knowledge sharing sebagai implementasi ruang inovasi pustakawan, kolaborasi sebagai perluasan ruang inovasi komunitas, dan inovasi sebagai siklus akhir inovasi komunitas.

Tema pertama yaitu latar belakang pustakawan untuk bergabung dalam komunitas dan menjadikannya sebagai motivasi komunal yang mampu berperan sebagai penggerak di komunitas untuk terus melakukan aktivitas berbagi pengetahuan. Seorang individu memiliki motivasi awal saat bergabung ke Komunitas SLiMS Semarang biasanya terkait dengan berbagai hal, mulai dari tuntutan pekerjaan, keinginan meluaskan jejaring, meningkatkan kompetensi profesional hingga meningkatkan derajat profesi. Seperti yang diutarakan informan berikut ini.

"Alasan bergabung dengan Komunitas SLiMS itu sejujurnya tuntutan, terlebih saya dulu kurang menguasai dan f[p]aham dengan aplikasi SLiMS ini. Tapi karena atasan memerintah saya untuk menguasai aplikasi, salah satu cara yang saya lakukan belajar, belajarnya dengan cara masuk ke dalam komunitas. Dari yang sebelumnya tidak menguasai sama sekali, apa itu SLiMS, akhirnya setelah masuk komunitas saya dapat teman untuk belajar. Bisa dibilang masuk komunitas karena keterpaksaan juga tapi akhirnya saya bisa, poinnya di 
situ" (Bimantara, wawancara, April 25, 2019).

Berdasarkan hasil wawancara, informan telah mengetahui bahwa Komunitas SLiMS Semarang merupakan suatu tempat untuk belajar dan melakukan inovasi. Hal ini menjadikan para pustakawan tertarik bergabung agar dapat membantu kebutuhan informasi berkaitan dengan pekerjaan dan peningkatan kemampuan inovasi. Selain itu, komunitas merupakan pilihan yang tepat buat para pustakawan sebagai tempat melakukan diskusi dan berbagi informasi di luar lokasi rutinitas kerja. Setiap individu pun mendapatkan suasana yang baru dan berbeda dari pertemuan dengan kolega dari perpustakaan lain sehingga mengarahkan motivasi ke daya imajinasi dan semangat kerja dalam pengembangan SLiMS.

Peneliti melihat bahwa motivasi individu yang terkumpul dari beragam latar belakang di Komunitas SLiMS Semarang justru membuat komunitas ini kuat. Motivasi yang terkumpul ialah motivasi komunal yang mampu menggerakkan orang-orang untuk mengembangkan dan memberikan kontribusi di komunitas dalam perkembangan SLiMS itu sendiri.

Salah satu contohnya ialah kegiatan pertukaran pengetahuan yang memberikan stimulan awal dalam memunculkan inovasi di komunitas. Hasil inovasi yang dibuat pun tidak lepas dari modal pengetahuan sosial yang dibagikan kepada sesama anggota komunitas. Hal ini mengingat bahwa pustakawan yang berkumpul di komunitas berasal dari berbagai latar belakang instansi, seperti pustakawan di universitas, sekolah tinggi, atau perpustakaan khusus yang menjadikan pustakawan memiliki pengalaman yang berbeda dan bermanfaat untuk saling dibagikan satu sama lain. Motivasi individu yang ada dalam komunitas ini juga telah memengaruhi kebiasaan kolaborasi dalam menghasilkan sebuah pengetahuan di komunitas (Arazy, Gellatly, Brainin, \& Nov, 2015). Hal ini selaras dengan pernyataan Jeon, Kim, and Koh (2011) yang menyatakan bahwa unsur intrinsik menjadi faktor yang lebih mendorong dalam melakukan knowledge sharing daripada faktor ekstrinsik. Kelompok intrinsik dapat mengatur diri sendiri dengan tujuan mengembangkan pengetahuan dan meningkatkan kinerja, melalui interaksi antara para anggotanya.

Komunitas SLiMS Semarang memiliki motivasi komunal yang berguna untuk keberlanjutan komunitas, namun komunitas pun bersifat self organized, yakni komunitas tidak memiliki kewajiban untuk terus melaksanakan kegiatan berbagi pengetahuan dalam community of practice. Maka, komunitas pun dibutuhkan komitmen yang kuat dari anggota agar komunitas terus berjalan. Hal tersebut sesuai dengan yang disebutkan Retna (2011) bahwa faktor kunci untuk merawat keberlangsungan community of practice dan mempromosikan pembelajaran inovatif serta lingkungan berbagi pengetahuan salah satunya adalah melalui motivasi. Nemec and LaMaster (2014) bahkan menyebutkan komitmen merupakan salah satu kunci utama untuk mempertahankan community of practice sehingga mereka menyarankan sebuah komunitas harus membentuk sebuah kelompok inti yang berguna untuk memotivasi dan mempertahankan community of practice. Kelompok inti ini harus memiliki komitmen dalam mengembangkan sebuah community of practice.

Tema kedua ialah knowledge sharing. 
Tema ini menjelaskan tentang kegiatan utama dalam Komunitas SLiMS Semarang yang berlangsung sebagai ruang inovasi, bagaimana komunitas ini mempertahankan serta mampu memperluas jangkauan. Knowledge sharing dalam penelitian ini adalah kegiatan saling berbagi pengetahuan antar anggota untuk mengembangkan dan menciptakan inovasi. Komunitas SLiMS Semarang adalah salah satu komunitas yang fokus pada kegiatan saling berbagi pengetahuan mengenai perkembangan dunia perpustakaan khususnya aplikasi SLiMS. Knowledge sharing sebagai salah satu kegiatan yang tidak bisa lepas dan inti dari komunitas yang dilakukan secara rutin, yang kemudian dimanifestasikan dengan beragam bentuk serta kegiatan.

Salah satu informan mengatakan bahwa,

"Komunitas SLiMS Semarang memiliki program yang beragam seperti, ada yang namanya Sinau Bareng bisa untuk internal atau umum. Di kegiatan itu, kita bisa belajar koding [code], modifikasi aplikasi, diskusi perpustakaan dan lain-lain. Ada juga Klinik Perpustakaan, yang memfasilitasi perpustakaan sekolah untuk belajar lebih dalam tentang software dan khususnya perpustakaan secara umum. Dan yang paling umum pelatihan SLiMS, biasanya kita ini diundang mahasiswa" (Wawan, wawancara, March 30, 2019).

Sesuai pernyataan informan tersebut dapat diketahui bahwa ada beragam kegiatan yang dilakukan Komunitas SLiMS Semarang. Kegiatan ini berisi aktivitas knowledge sharing dan kegiatan praktis seperti belajar koding (code) dan modifikasi secara langsung serta bersama-sama. Komunitas SLiMS Semarang sesuai kegiatan yang telah diadakan sebagai bukti bahwa komunitas ini telah transformasi diri sebagai ruang inovasi bagi pustakawan.

Kegiatan knowledge sharing yang dilakukan komunitas SLiMS Semarang pun lebih beragam dan jangkauannya luas. Komunitas dapat menjangkau intra pengurus dan menjangkau luar kelompok, berupa pelatihan, pendampingan, seminar tentang SLiMS pada beberapa perpustakaan dan para pengurus. Adapun kegiatan utama komunitas berupa "Sinau Bareng" yang dilaksanakan dengan dua jenis peserta, yaitu khusus pengurus internal dan peminat dari luar komunitas.

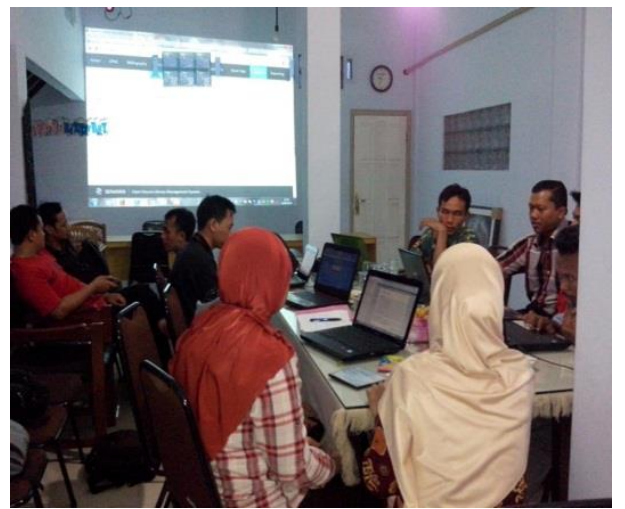

Gambar 1. Kegiatan komunitas SLiMS Semarang "Sinau Bareng"

Sumber: Koleksi internal Komunitas SLiMS Semarang, 2019

Kegiatan "Sinau Bareng" dilakukan dengan peserta dari luar komunitas sebagai sarana berbagi pengetahuan dan promosi dari komunitas itu sendiri. Seperti yang diungkapkan informan.

“Tujuan masuk komunitas dan melakukan sharing knowledge, supaya nantinya bisa menarik teman-teman untuk ikut dan berkarya di Komunitas SLiMS. Bagus jika teman lain bisa bergabung dan mengangkat derajat profesi pustakawan" (Erik, wawancara, March 29, 2019). 
Komunitas SLiMS Semarang berdasarkan kegiatan-kegiatan yang dilakukan secara langsung ataupun tidak langsung berfungsi dapat memperluas dan memperbesar jaringan komunitas. Selain itu, dari kegiatan yang diadakan pun dapat meningkatkan potensi pengetahuan dan sumber daya Komunitas SLiMS Semarang agar dapat diimplementasikan sebagai ruang inovasi pustakawan. Dengan demikian, pengetahuan dan sumber daya kolektif anggota Komunitas SLiMS Semarang akan berpotensi meningkatkan knowledge sharing dalam komunitas tersebut.

Adapun knowledge sharing yang diimplementasikan dalam berbagai bentuk dapat meluaskan jejaring dan interaksi sekaligus saling bertukar ide, gagasan tentang keilmuan hingga bertukar praktik terbaik dalam pengembangan dan inovasi SLiMS. Komunitas SLiMS Semarang membentuk community of practice yang dinamis dan memiliki keinginan untuk terus berkembang searah perkembangan zaman dan kebutuhan anggota. Hal ini merupakan penentu sukses atau tidaknya komunitas untuk mampu berevolusi. Community of practice sebagai kunci Komunitas SLiMS Semarang dalam berevolusi karena sifatnya yang dinamis.

Seiring pertumbuhan komunitas, anggota baru yang bergabung di Komunitas SLiMS Semarang membawa kepentingan baru dan fokus komunitas ke arah yang berbeda. Maka, output dari kegiatan komunitas adalah mampu meningkatkan kemampuan pustakawan sekaligus mendorong mereka untuk berkarya. Hal ini sesuai pernyataan Holmes, Greenhill, and McLean (2014) yang menyatakan bahwa ketika individu merupakan bagian sebuah community of practice maka memungkinkan mereka terhubung dengan orang lain, membangun usaha kreatif, dan belajar atau meningkatkan keterampilan.

Berdasarkan kegiatan di Komunitas SLiMS Semarang, pertama yang didapatkan adalah sebuah interaksi pengetahuan yang berpengaruh pada peningkatan pengetahuan dan inovasi anggota. Komunitas ini sebagai ruang pemantik belajar dengan jejaring yang dimiliki komunitas dengan bermodalkan sumber daya manusia. Community of practice merupakan kegiatan interaksi antar anggota atau kelompok lain yang sangat penting untuk dilakukan. Komunitas SLiMS Semarang terus mencoba mengikat keterhubungan pengetahuan antaranggota melalui interaksi. Interaksi dapat merangsang munculnya pengetahuan bersama yang berujung pada sebuah inovasi menggunakan media virtual.

Media virtual digunakan untuk mempertahankan rutinitas kegiatan berbagi pengetahuan dan interaksi antar pengurus. Selain itu, para pengurus pun menggunakan grup daring seperti WhatsApp, Facebook, dan Blog. Kegiatan yang berbasis daring sebagai bagian tidak terpisahkan dalam Komunitas SLiMS Semarang karena dari awal komunitas ini terbentuk melalui bantuan media daring. Salah satu media yang digunakan sebagai sarana bertukar ide adalah Blog komunitas, untuk berbagi pengetahuan seputar tutorial, modifikasi, dan plug-in. Walaupun demikian, penggunaan media daring di komunitas ini masih mengalami beberapa kendala, seperti yang dituturkan informasi.

"Mungkin kita rutin bertemu tapi intensitasnya tidak seperti dulu. Jadi, ya, tadi yang disebut itu seperti WhatsApp dan yang lain (Facebook dan $B \log$ ). Itu selain membantu komunitas 
ini dalam share pengetahuan atau inovasinya juga menjadi tantangan tersendiri" (Bimantara, wawancara, April 25, 2019).

Sesuai keterangan di atas diketahui bahwa pengembangan komunitas yang menggunakan media daring memang tidak selalu berjalan lancar. Komunitas akan mengalami beberapa hambatan, seperti aspek interpersonal, prosedural, teknologi hingga budaya (Philpott \& Pike, 2013). Walaupun begitu, Komunitas SLiMS Semarang terus mengembangkan sistem pembelajaran berbasis media daring dengan cara menyediakan akses pengetahuan bersama, membangun kepercayaan, dan mempertahankan komunikasi yang dilakukan komunitas sebagai alat bantu menjaga ritme keberlangsungan komunitas. Komunikasi yang dilakukan di komunitas ini disebut informan sebagai bentuk sebuah inovasi dalam knowledge sharing yang disertai praktik dengan berbagai bentuk dan ragam sebagai kegiatan utama Komunitas SLiMS Semarang.

Komunitas ini membantu para praktisi perpustakaan dari waktu ke waktu dengan cara memfasilitasi transfer pengetahuan dan membangun kegiatan praktik bersama sebagai penguat eksistensi komunitas. Terlebih lagi adanya grup daring dan Blog membuat jaringan dan kesempatan untuk berkolaborasi dengan komunitas lain terbuka lebar. Hal tersebut didukung pernyataan Page, Hynes, and Reed (2018) yang menyebutkan bahwa komunikasi melalui media daring bermanfaat mengembangkan komunitas virtual yang memungkinkan meluasnya peer support dan peer review hingga pengembangan jaringan kelompok.

Tema ketiga, kolaborasi mengenai interaksi dalam lingkup yang lebih luas daripada sekadar interaksi antar anggota. Kolaborasi sebagai bentuk interaksi yang mampu menghasilkan inovasi yang berbeda dari inovasi yang biasa diciptakan oleh komunitas. Kolaborasi secara tidak langsung mampu memperluas ruang inovasi sehingga anggota komunitas mampu bertukar pengetahuan yang sepenuhnya baru dengan komunitas lain. Kegiatan kolaborasi yang dilakukan Komunitas SLiMS Semarang melalui pertemuan secara langsung atau daring sehingga membuat komunitas ini terus berkembang.

Beberapa informan memilih untuk meningkatkan inovasi dengan memulai kolaborasi dengan komunitas lain, baik Komunitas SLiMS, komunitas perpustakaan secara umum, dan komunitas lainnya. Kolaborasi yang dilakukan anggota Komunitas SLiMS Semarang mampu menimbulkan banyak efek, seperti kolaborasi sebagai pemantik belajar, menghasilkan sebuah inovasi, dan menambah pengetahuan baru. Longo and Narduzzo (2017) pun menuturkan bahwa komunitas yang melibatkan banyak individu dalam sebuah kelompok praktik dalam riset dan pengembangan yang berorientasi pada inovasi memiliki kemungkinan besar menghasilkan dampak positif bagi proyek yang sedang dikerjakan.

Selain itu, kegiatan kolaborasi juga dapat membuat informan mampu mengisi keterbatasan yang dimiliki dalam sebuah inovasi. Maka, kolaborasi yang dilakukan sebagai ruang inovasi menjadi berkurang batasannya. Hal ini sesuai penyampaian informan.

"Keterbatasan itu mampu dikurangi, ya, sebetulnya asal mau kolaborasi. Contohnya dalam membuat inovasi Saya bersama orang dari luar 
komunitas SLiMS Semarang. Waktu itu, dia punya gagasan tapi tidak bisa coding terus bagaimana kita bikin plug-in ini. Waktu itu jenis vocabulary control kalo gak salah. Itulah kolaborasinya dan sekarang bahkan programnya sudah masuk repositorinya SLiMS. Bukan lagi plug-in tapi sudah masuk resmi dalam program. Terus itu kan penelitian, masuk jurnal juga. Jadi sama-sama saling menguntungkan" (Wawan, wawancara, March 30, 2019).

Data tersebut menunjukkan bahwa anggota yang mengalami kekurangan pengetahuan ketika praktik dapat terbantu oleh sesama rekan saat kolaborasi. Maka, inovasi yang dihasilkan pun akan lebih luas dibandingkan inovasi intra komunitas. Anggota dalam komunitas yang melakukan kegiatan berbagi pengetahuan kepada individu di luar komunitas akan memiliki pengetahuan berbeda dibandingkan anggota dalam komunitas yang saling berbagi pengetahuan kepada intra kelompok yang rutin melakukan pertemuan. Anggota akan menerima ruang yang lebih luas dari pengetahuan dan inovasi yang hasil berbagi pengetahuan dengan individu di luar komunitas.

Anggota Komunitas SLiMS Semarang yang melakukan kegiatan kolaborasi akan mendapatkan keterbukaan dialog di antara sudut pandang yang berbeda. Sánchez-Cardona, Sánchez-Lugo, and VŽlez-González (2012) menyebutkan bentuk kolaborasi ini sebagai CoPs, kolaborasi antar peserta dan pembentukan jaringan serta aliansi profesional. Interaksi antara anggota komunitas meningkatkan pengetahuan, akses ke pengalaman yang berbeda, dan meningkatkan keahlian setiap peserta, yang mengarah pada peluang untuk terlibat dalam proyek kelembagaan di masa depan. Maka hal ini dimemerlukan perspektif dari luar untuk membantu anggota komunitas untuk melihat kemungkinan potensi tersebut. Selain itu, kolaborasi pun secara tidak langsung telah membawa pengetahuan baru bagi Komunitas SLiMS Semarang sendiri. Individu yang melakukan berkolaborasi akan membagikan pengetahuan yang dimilikinya ke individu dalam komunitas. Alhasil pengetahuan baru yang didapatkan pun sebagai pengetahuan individu dan pengetahuan komunitas secara organisasi.

Hal ini disebut sebagai internalisasi, yaitu sebuah proses pembelajaran dan akuisisi pengetahuan yang dilakukan anggota organisasi terhadap explicit knowledge yang disebarkan ke seluruh organisasi melalui pengalaman sendiri dan berubah ke tacit knowledge anggota organisasi (Hadari, 2012).

Tema terakhir yang didapatkan anggota Komunitas SLiMS Semarang adalah inovasi. Tema ini menjelaskan mengenai suatu hasil akhir kegiatan yang telah berjalan melalui berbagai tahapan. Anggota melalui inovasi menambah pengetahuan lain muncul kemudian berkembang dalam komunitas. Inovasi dalam penelitian ini terkait inovasi Komunitas SLiMS Semarang dalam pengembangan SLiMS, baik kegiatan, produk, hingga ide. Inovasi yang muncul merupakan hasil kegiatan pertukaran pengetahuan komunitas dengan komunitas lainnya melalui motivasi, knowledge sharing, dan kolaborasi. Maka ketiga hal ini sebagai bagian tahapan munculnya sebuah inovasi dalam Komunitas SLiMS Semarang.

Ada dua jenis inovasi yang muncul dalam komunitas, inovasi individu dan 
inovasi kelompok. Inovasi individu ialah inovasi yang dihasilkan individu di komunitas dalam berbagai bentuk, umumnya, di antaranya plug-in, template, tutorial, modifikasi, hingga program yang sepenuhnya baru. Inovasi yang dihasilkan individu biasanya digunakan sebatas keperluan personal pekerjaan. Di mana inovasi yang dihasilkan melalui kolaborasi antar individu dalam komunitas atau pertukaran pengetahuan yang melalui komunitas lain. Hal tersebut seperti yang dijelaskan informan.

"Aku ada beberapa jenis (inovasi) yang dibuat, yang pertama template, plug-in, dan tools. Kebanyakan sih template terus plug-in kartu angota, kemudian label, dan yang paling besar Aku sekarang menjadi salah satu pengembang untuk Setiadi Senayan: Thesis and Dissertation System" (Erik, wawancara, March 29, 2019).

Inovasi dapat dihasilkan oleh individu dan muncul dalam bentuk lain. Seluruh anggota memiliki kolektivitas ide dari komunitas kemudian berubah ke inovasi komunitas. Inovasi ini muncul dalam kegiatan belajar komunitas dan berfungsi sebagai sarana berbagi pengetahuan kepada kelompok luar komunitas untuk dibagikan dalam forum umum, contohnya tutorial, plug-in, tools, desain, dan merchandise. Hal tersebut seperti disampaikan informan berikut.

"Dalam inovasi komunitas, Kita ada beragam dan kontribusi terkait inovasi tidak harus membuat produk berupa tutorial atau plug-in misalnya. Kita juga bisa dalam bentuk merchandise, atau design karena Komunitas SLiMS Semarang juga punya produk merchandise. Selain itu, inovasi lain juga banyak seperti kegiatan acara baru, seminar atau workshop, dan itu semua muncul dalam kegiatan belajar bersama di komunitas" (Bimantara, wawancara, April 25, 2019).

Inovasi individu dan kelompok Komunitas SLiMS Semarang tidak berhenti dalam suatu pengetahuan. Inovasi yang telah dihasilkan akan dibagikan lagi dalam komunitas melalui media daring atau langsung tatap muka. Inovasi yang ada berubah ke modal pengetahuan dan membuat inovasi baru. Selain itu, inovasi atau hasil produk kolaborasi pun dapat meningkatkan motivasi intrinsik anggota komunitas, seperti kebutuhan untuk berprestasi, berafiliasi, dan meningkatkan kemampuan membuat karya dalam penyelesaian inovasi selama proses interaksi dengan orang lain (Wang, Zhang, Hao, \& Chen, 2019). Inovasi berbentuk beragam karena komunitas tidak membatasi diri mengenai tujuan tunggal kelompok saja. Komunitas menyerahkan otonomi kepada anggota agar anggota dapat mengeksplorasi arah inovatif dan inovatif yang berbeda dari rutinitas konvensional organisasi (Borzillo, \& Kaminska-Labbé, 2011). Community of practice memiliki peran dalam pembelajaran dan inovasi organisasi. Di mana anggota dapat berbagi, mengembangkan pengetahuan, dan praktik hal baru bersama-sama secara sukarela (Bardon, \& Borzillo, 2016).

Inovasi merupakan tahapan akhir dalam proses pengetahuan dalam Komunitas SLiMS Semarang, namun hal ini tidak menjadikan proses pengetahuan tersebut terhenti. Inovasi justru sebagai awalan baru dalam pengembangan produk baru sebab terjadinya inovasi yang dibagikan kembali kepada anggota komunitas lainnya. Seperti dinyatakan informan berikut. 
"Untuk membuat sebuah inovasi karena prinsipnya berbagi, karena Saya dapat ilmu dari komunitas, ya, Saya bagi lagi ke komunitas biar nanti nggak hilang pengetahuannya, plus bisa dikembangkan lagi. Itu sebab-nya sharing-nya, ya, harus ke komunitas lagi. Biar nantinya bisa muncul ide lain atau pengembangan ide dari yang sudah di-share atau dibuat sebelumnya" (Bimantara, wawancara, April 25, 2019).

Sesuai penjelasan ini, antara tema satu dengan yang lainnya memiliki keterkaitan dan saling memengaruhi. Keempat tema yang telah diuraikan sebelumnya merupakan deskripsi dari pola yang terkait dengan komunitas sebagai ruang inovasi pustakawan. Hal ini diilustrasikan dalam gambar 2 .

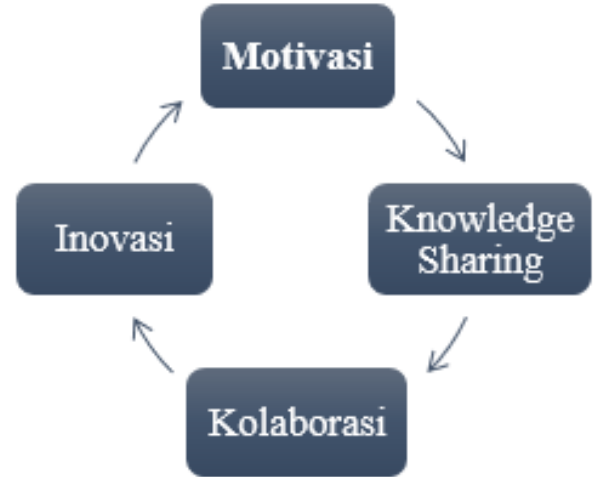

Gambar 2. Siklus inovasi Komunitas SliMS Semarang

Sumber: Hasil penelitian, 2019

Motivasi merupakan tema pertama yang memengaruhi seluruh kegiatan yang dilakukan Komunitas SLiMS Semarang. Semangat yang beragam muncul dari individu yang berbeda sehingga motivasi individual sekaligus motivasi komunitas. Motivasi dalam aspek inti dari terlaksananya kegiatan komunitas, termasuk kegiatan berbagi pengetahuan yang dilakukan anggota Komunitas SLiMS Semarang. Apabila anggota komunitas tanpa didukung motivasi berbagi pengetahuan maka seluruh kegiatan yang dilakukan dalam komunitas tidak akan terlaksana. Maka, tema motivasi memengaruhi tema lain pada tahapan selanjutnya.

Tema kedua yaitu knowledge sharing. Secara umum, sebuah community of practice memiliki kegiatan berbagi pengetahuan dan praktik yang berisikan kegiatan interaksi. Knowledge sharing yang berjalan secara rutin dan diperluas jangkauannya melalui penggunaan media daring yang semakin berpotensi terjadinya kolaborasi dalam komunitas juga luar Komunitas SLiMS Semarang. Tema knowledge sharing tidak lepas dari tema motivasi karena salah satu motivasi individual anggota ialah ingin melakukan inovasi dan membangun jejaring antar pustakawan pengguna SLiMS. Tema knowledge sharing pun memengaruhi tema ketiga, yakni kolaborasi karena anggota komunitas ingin membuat inovasi lebih lebih luas lagi.

Tema ketiga adalah kolaborasi. Anggota melalui kolaborasi akan berkembang lebih luas. Komunitas dalam kolaborasi berperan sebagai pengantar ke dalam ranah interaksi yang berbeda. Kolaborasi telah melebarkan fokus terhadap anggota komunitas. Di mana pengetahuan baru hasil interaksi dengan kelompok lain akan membawa pengetahuan baru masuk, yang nantinya disebar ke dalam komunitasnya sendiri.

Inovasi merupakan tema terakhir dalam siklus pengetahuan dalam Komunitas SLiMS Semarang. Sesuai gambar 2, kegiatan yang dilaksanakan komunitas bermuara pada hasil, baik inovasi yang bersifat individu atau inovasi komunitas. Namun, adanya tahapan terakhir, inovasi, menandakan bahwa proses pengetahuan terhenti. Justru dalam inovasi, hasil yang sudah dicapai akan 
dijadikan modal pengetahuan awal untuk membuat sebuah inovasi baru dan mendorong terjadinya kegiatan lain dalam Komunitas SLiMS Semarang.

\section{SIMPULAN}

Komunitas SLiMS Semarang mampu memunculkan sebuah rangkaian kegiatan yang mengarah ke dalam sebuah inovasi. Sebagian besar anggota aktif dalam memberikan motivasi dan mengajak aktivitas berbagi pengetahuan. Pengulangan kegiatan yang dilakukan pada dasarnya merupakan keinginan besar setiap anggota dalam berbagi pengetahuan yang kemudian berwujud kolaborasi antar anggota dalam melakukan kegiatan selanjutnya. Kolaborasi yang dilakukan adalah stimulasi lanjutan yang pada akhirnya memunculkan inovasi para anggota komunitas. Pada penelitian selanjutnya, peneliti dapat melakukan kajian tentang pengaruh community of practice khususnya Komunitas SliMS Semarang dalam peningkatan kompetensi pustakawan. Penelitian yang menganalisis terhadap pengaruh agar dapat lebih bermanfaat secara praktis bagi pustakawan dan secara keilmuan bagi peneliti di bidang kepustakawanan dan manajemen pengetahuan.

\section{DAFTAR PUSTAKA}

Abou-Setta, A. (2015). Revisiting communities of practice - the case of Egyptian graffitists. Higher Education, Skills and Work-Based Learning, 5(2), 135-151. https://doi.org/10.1108/HESWBL02-2014-0005

Arazy, O., Gellatly, I., Brainin, E., \& Nov, O. (2015). Motivation to share knowledge using wiki technology and the moderating effect of role perceptions. Journal of the Association for Information Science and Technology, 67(10), 2362-2378.

https://doi.org/10.1002/asi.23579

Bardon, T., \& Borzillo, S. (2016). Communities of practice: Control or autonomy? Journal of Business Strategy, 37(1), 11-18. https://doi.org/10.1108/JBS-02-201 5-0018

Borzillo, S., \& Kaminska-Labbé, R. (2011). Unraveling the dynamics of knowledge creation in communities of practice through complexity theory lenses. Knowledge Management Research and Practice, 9(4), 353-366. https://doi.org/10.1057/kmrp.2011 .13

Britt, V. G., \& Paulus, T. (2016). Beyond the four walls of my building": A Case study of \#Edchat as a community of practice. American Journal of Distance Education, 30(1), 48-59.

https://doi.org/10.1080/08923647.2 016.1119609

Hadari, N. (2012). Metode penelitian bidang sosial. Yogyakarta: UGM Press.

Heriyanto. (2018). Thematic analysis sebagai metode menganalisa data untuk penelitian kualitatif. Anuva: Jurnal Kajian Budaya, Perpustakaan, Dan Informasi, 2(3), 317-324. https://doi.org/10.14710/anuva.2.3 .317-324

Holmes, K., Greenhill, A., \& McLean, R. (2014). Creating communities: The use of technology in craft and DIY communities of practice. Journal of Systems and Information Technology, 16(4), 277-295.

https://doi.org/10.1108/JSIT-05-20 13-0018

Jeon, S., Kim, Y., \& Koh, J. (2011). An integrative model for knowledge sharing in communities of practice. Journal of Knowledge Management, 15(2), 251-269.

https://doi.org/10.1108/136732711 


\section{2}

Longo, M. C., \& Narduzzo, A. (2017). Transactive knowledge from communities of practice to firms: An Empirical investigation of innovative projects performance. European Journal of Innovation Management, 20(2), 291-311. https://doi.org/10.1108/EJIM-10-20 16-0098

Mohajan, H. K. (2017). Roles of communities of practice for the development of the society. Journal of Economic Development, Environment and People, 6(3), 27-46. Retrieved from

http:/ /ojs.spiruharet.ro/index.php/ jedep/article/view/63174/pdf

Moleong, L. J. (2017). Metodologi penelitian kualitatif. Bandung: Remaja Rosdakarya.

Nemec, P. B., \& LaMaster, S. (2014). Education and training column: Communities of practice. Psychiatric Rehabilitation Journal, 37(4), 336-338. https://doi.org/10.1037/prj0000081

Page, R., Hynes, F., \& Reed, J. (2018). Distance is not a barrier: The Use of videoconferencing to develop a community of practice. The Journal of Mental Health Training, Education and Practice, 14(1), 12-19.

https://doi.org/10.1108/JMHTEP-1 0-2016-0052

Philpott, E., \& Pike, D. (2013). Virtual-team-community-of-practice (VTCoP) theory can inform online course delivery. Journal of Applied Research in Higher Education, 5(2), 222-238.

https://doi.org/10.1108/JARHE-112012-0033

Ranmuthugala, G., Plumb, J. J., Cunningham, F. C., Georgiou, A., Westbrook, J. I., \& Braithwaite, J. (2011). How and why are communities of practice established in the healthcare sector? A systematic review of the literature. BMC Health Services Research, 11(273), 1-16. Retrieved from https:/ / bmchealthservres.biomedce ntral.com/track/pdf/10.1186/14726963-11-273.pdf

Retna, K. S. (2011). Communities of practice: Dynamics and success factors. Human Resource Management International Digest, 19(4), 41-60. https:/ / doi.org/10.1108/hrmid.201 1.04419daa.008

Sánchez-Cardona, I., Sánchez-Lugo, J., \& VŽlez-González, J. (2012). Exploring the potential of communities of practice for learning and collaboration in a higher education context. Procedia: Social and Behavioral Sciences, 46(16), 1820-1825.

https://doi.org/10.1016/j.sbspro.20 12.05.385

Sugiyono. (2016). Metode penelitian kuantitatif, kualitatif dan $R \in \mathcal{E} D$. Bandung: Alfabeta.

Wang, J., Zhang, R., Hao, J.-X., \& Chen, X. (2019). Motivation factors of knowledge collaboration in virtual communities of practice: A Perspective from system dynamics. Journal of Knowledge Management, 23(3), 466-488.

https://doi.org/10.1108/JKM-02-20 18-0061

Wenger-Trayner, E., \& Wenger-Trayner, B. (2015). Communities of practice a brief introduction. Wenger-Trayner.Com. Retrieved from

https://wenger-trayner.com/wp-co ntent/uploads/2015/04/07-Brief-int roduction-to-communities-of-practic e.pdf

Widodo, O. C. (2016). Efektifitas penggunaan software open source (SLiMS) pada perpustakaan perguruan tinggi di Malang. Libri-Net, 6(1), 5-6. Retrieved from http://journal.unair.ac.id/downloa d-fullpapers-lncd09f5046afull.pdf 